\title{
The Influence of Marketing, Promotion and Reputation Strategies on Purchasing Decisions in Savings and Loans Cooperatives in South Tangerang
}

\author{
Fauziah Septiani $^{1}$, Suharni Rahayu ${ }^{2}$, Risza Putri Elburdah ${ }^{3}$ \\ ${ }_{1,2,3}$ Universitas Pamulang \\ E-mail: dosen01771@unpam.ac.id
}

\begin{abstract}
Each cooperative must have the right marketing strategy, such as further increasing the productive capacity of its members, so that they can face market competition which merely emphasizes the norm of efficiency. This study aims to determine the marketing strategy, promotion, and reputation of purchasing decisions at the Savings and Loan Cooperative in South Tangerang. The method used was explanatory research with a sample of 90 respondents. The analysis technique uses statistical analysis with regression testing, correlation, determination, and hypothesis testing. The results of this study's marketing strategies significantly influence purchasing decisions by $33.2 \%$, hypothesis testing obtained significance 0,000 $<0.05$. The promotion has a significant effect on purchasing decisions of $36.6 \%$, hypothesis testing is obtained significance of $0,000<0.05$. Reputation has a significant effect on purchasing decisions by $26.9 \%$, hypothesis testing obtained significance $0,000<0.05$. Marketing strategy, promotion, and reputation simultaneously have a significant effect on purchasing decisions by $51.4 \%$, hypothesis testing obtained significance $0,000<0.05$.
\end{abstract}

Keywords: Marketing strategies; promotions; reputation; purchasing decisions

\section{INTRODUCTION}

In Indonesia, many people do not understand the benefits and advantages of being a member of a cooperative due to the lack of information received due to less than maximum marketing, promotion, and reputation strategies. People's economy is an economic activity that is in favor of the community, especially in improving the economy of the community in particular and the government in general (Farida, 2017; Niswaty et al., 2016). Cooperative itself is an economic activity that makes its members prosperous because the cooperative is an economic activity of members for members, which can prosper the members of the cooperative are members of the cooperative itself (Irmal et al., 2020).

In its development, the types of cooperatives that develop tend to vary. This diversity is certainly strongly influenced by the background of the formation and goals to be achieved by each cooperative. Cooperatives can then be classified into several large groups based on the approach. Cooperative grouping based on the business sectors such as consumer cooperatives, production cooperatives, marketing cooperatives, and credit/savings and credit cooperatives. In this study, we specialize cooperatives engaged in Savings and Loans. Looking at the decline in the amount of savings and loans, especially in loan transactions due to cooperatives not using a marketing mix strategy, there is still a lack of promotion carried out by cooperatives, there are still many members who do not believe in the existence of cooperatives. 


\section{Jurnal Administrare: Jurnal Pemikiran Ilmiah dan Pendidikan Administrasi Perkantoran Vol. 7, No. 1, January - June 2020, Pages 109-116}

Each cooperative must have an appropriate marketing strategy, such as further increasing the productive capacity of its members so that they can face market competition which merely emphasizes the norm of efficiency (Hollensen, 2010; Parola et al., 2018; Peter et al., 1999). This is in line with what was said (Mani, 2018) that the strategy in marketing is an important asset owned by a company because the strategy is a tool to achieve the desired goals that are to achieve maximum sales levels and get the maximum profit. Further explained that competition in business can certainly make the industry and market more attractive, the high intensity of rivalry is characterized by the application of marketing strategies such as what can win the hearts of customers makes its value for the company. Competitor products that will enter the same market or the same segmentation must also have a competitive advantage (Ferrara et al., 2019; Ferrari et al., 2017; Roy et al., 2017)

The superiority of a product is not guaranteed to be the people's choice (Chenavaz et al., 2020; Steinhauser et al., 2019; Wen \& Siqin, 2020). A product requires a way to be known to the wider community. This method finally talks to the public that a product is worthy to be chosen because of excellence or other reasons. Marketing a product requires communication tools or media to introduce the product to the target market (Jiménez-Asenjo \& Filipescu, 2019; Krämer et al., 2017; Varadarajan, 2020). This communication tool to connect producers and consumers is called promotion. Promotion is an activity carried out by a company that aims to inform, persuade, influence, and remind consumers to buy products from the company. The purpose of promotion is to get attention, educate, remind, and convince potential customers (Ma \& Koutsopoulos, 2019; Mead et al., 2020; Yang \& Mattila, 2020).

Promotional activities are very important so that the products provided by savings and loan cooperatives can be known and subsequently consumer interest arises to choose according to their needs (Deng et al., 2018; Zaric \& Xie, 2009). If consumer interest has arisen, it will be very large later to determine purchasing decisions on savings and loan products available in cooperatives. Promoting the product is one thing that is very important for business progress, because, without the promotion, we can be sure that product sales will not succeed optimally. To be able to provide maximum results in promotional activities, some stages can be carried out by savings and credit cooperatives in product promotion. One of the stages in determining the target market and choosing the right media for promotion.

A reputation is built on corporate identity as the first point reflected through company names (logos) and other displays, for example from annual reports, brochures, product packaging, office interior, employee uniforms, advertisements, media coverage, written material, and social audio. Corporate identity is also non-physical, such as corporate values and philosophy, service, work style, and communication, both internal and external. The current reputation that is reflected in savings and loan cooperatives is an award that is obtained because of the advantages of the cooperative, namely the ability possessed by cooperatives so that they will continue to develop themselves to be able to create new things to meet the needs of consumers of each savings and loan cooperative.

\section{METHOD}


The type of research used is associative, where the aim is to find out the search for interconnection. The population in this study amounted to 90 respondents of Saving and Credit Cooperatives in South Tangerang. The sampling technique in this study is saturated sampling, where all members of the population are sampled. Thus the sample in this study amounted to 90 respondents. In analyzing the data used the instrument test, classical assumption test, regression, coefficient of determination, and hypothesis testing.

\section{RESULT AND DISCUSSION}

This test used to determine the highest minimum and maximum scores, ratting scores, and standard deviations of each variable. The results are as follows:

Table 1.

\section{Descriptive Statistics Analysis Results}

\section{Descriptive Statistics}

\begin{tabular}{l|r|r|r|r|r}
\hline & N & Minimum & Maximum & Mean & Std. Deviation \\
\hline Marketing Strategy (X1) & 90 & 29 & 46 & 37.26 & 3.677 \\
\hline Promotion (X2) & 90 & 30 & 46 & 36.93 & 3.355 \\
\hline Reputation (X3) & 90 & 30 & 46 & 37.56 & 3.703 \\
\hline Purchase Decision (Y) & 90 & 32 & 46 & 38.52 & 3.216 \\
\hline Valid N (listwise) & 90 & & & & \\
\hline
\end{tabular}

The marketing strategy obtained a minimum variance of 29 and a maximum variance of 46 with a rating score of 37.26 with a standard deviation of 3.677. Promotion obtained a minimum variance of 30 and a maximum variance of 46 with a rating score of 36.93 with a standard deviation of 3.355. Reputation obtained a minimum variance of 30 and a maximum variance of 46 with a rating score of 37.56 with a standard deviation of 3.703. The purchase decision obtained a minimum variance of 32 and a maximum variance of 46 with a rating score of 38.52 with a standard deviation of 3.216

\section{The Influence of Marketing Strategies on Purchasing Decisions}

Correlation coefficient analysis is intended to determine the level of relationship strength of the marketing strategy variable to the purchase decision variable. The test results are as follows:

Table 2. 
112 Jurnal Administrare: Jurnal Pemikiran Ilmiah dan Pendidikan Administrasi Perkantoran Vol. 7, No. 1, January - June 2020, Pages 109-116

Correlation Coefficient Testing Results of Marketing Strategies Against Purchasing Decisions

\section{Correlations $^{\mathrm{b}}$}

\begin{tabular}{llrr|r}
\hline & & $\begin{array}{c}\text { Marketing } \\
\text { Strategy (X1) }\end{array}$ & $\begin{array}{r}\text { Purchase Decision } \\
(Y)\end{array}$ \\
\hline Marketing Strategy (X1) & Pearson Correlation & 1 & $.576^{* *}$ \\
\cline { 2 - 4 } & Sig. (2-tailed) & & .000 \\
\hline Purchase Decision (Y) & Pearson Correlation & $.576^{* *}$ & 1 \\
\cline { 2 - 5 } & Sig. (2-tailed) & .000 & \\
\hline
\end{tabular}

**. Correlation is significant at the 0.01 level (2-tailed).

b. Listwise $\mathrm{N}=90$

Based on the results obtained from a value of 0.576 intent marketing strategies that have a relationship with the purchase decision.

Analysis of the coefficient of determination to determine the magnitude of the effect of the marketing variable strategy on the purchase decision variable. Results

Table 3.

Test Results for the Determination of the Marketing Strategy Coefficient on Purchasing Decisions

Model Summary

\begin{tabular}{lr|r|r|rr}
\hline & & & \multicolumn{2}{c}{$\begin{array}{c}\text { Std. Error of the } \\
\text { Estimate }\end{array}$} \\
\hline 1 & $\mathrm{R}$ & $\mathrm{R}$ Square & Adjusted R Square & 2.644 \\
\hline
\end{tabular}

a. Predictors: (Constant), Marketing strategy (X1)

Based on the test results obtained a determination value of 0.332 means that the marketing strategy has an influence contribution of $33.2 \%$ to the decision of the buyer

Hypothesis testing with a t-test is used to find out which partial hypotheses are accepted. The first hypothesis: there is a significant influence between marketing strategies on purchasing decisions.

Table 4.

Hypothesis Test Results of Marketing Strategies Against Purchasing Decisions

Coefficients $^{a}$

\begin{tabular}{|c|c|c|c|c|c|}
\hline \multirow[b]{2}{*}{ Model } & \multicolumn{2}{|c|}{$\begin{array}{c}\text { Unstandardized } \\
\text { Coefficients }\end{array}$} & \multirow{2}{*}{$\begin{array}{c}\text { Standardized } \\
\text { Coefficients } \\
\text { Beta } \\
\end{array}$} & \multirow[b]{2}{*}{$\mathrm{t}$} & \multirow[b]{2}{*}{ Sig. } \\
\hline & $\mathrm{B}$ & Std. Error & & & \\
\hline $1 \quad$ (Constant) & 19.757 & 2.854 & & 6.924 & .000 \\
\hline Marketing strategy (X1) & .504 & .076 & .576 & 6.607 & .000 \\
\hline
\end{tabular}

a. Dependent Variable: Purchase decision (Y) 
Based on the test results in the above table, the value of $t$ count $>t$ table or $(6.607>1.987)$ is obtained, thus the first hypothesis proposed that there is a significant influence on the marketing strategy on purchasing decisions is accepted

\section{The Influence of Promotion on Purchasing Decisions}

Correlation coefficient analysis is intended to determine the level of strength of the relationship of the promotion variable to the purchase decision variable. The test results are as follows:

Table 5.

Test Results Correlation Coefficient Promotion of Purchasing Decisions Correlations $^{\mathrm{b}}$

\begin{tabular}{llr|r}
\hline & & Promotion (X2) & \multicolumn{1}{c}{$\begin{array}{c}\text { Purchase } \\
\text { Decision }\end{array}$} \\
\hline Promotion (X2) & Pearson Correlation & 1 & $.605^{* *}$ \\
\cline { 2 - 4 } & Sig. (2-tailed) & & .000 \\
\hline Purchase Decision (Y) & Pearson Correlation & $.605^{* *}$ & 1 \\
\cline { 2 - 4 } & Sig. (2-tailed) & .000 & \\
\hline
\end{tabular}

**. Correlation is significant at the 0.01 level (2-tailed).

b. Listwise $\mathrm{N}=90$

Based on the test results obtained by the correlation value of 0.605 means that promotion has a strong relationship with the purchase decision.

The coefficient of determination analysis is intended to find out the percentage of the effect of the promotion variable on the purchase decision variable. The test results are as follows:

Table 6.

Test Results for Promotion Determination Coefficient on Purchasing Decisions Model Summary

\begin{tabular}{lrr|rrr}
\hline Model & & R & \multicolumn{2}{c}{$\begin{array}{c}\text { Adjusted R } \\
\text { Square }\end{array}$} & \multicolumn{2}{c}{$\begin{array}{c}\text { Std. Error of the } \\
\text { Estimate }\end{array}$} \\
\hline 1 & R Square & .366 & .359 & 2.575 \\
\hline
\end{tabular}

a. Predictors: (Constant), Promotion (X2)

Based on the test results obtained a determination value of 0.366 means that promotion has a contribution of $36.6 \%$ to the purchase decision.

Hypothesis testing with the t-test is used to accept which partial hypotheses are accepted. The second hypothesis: looks significant between promotions and purchasing decisions 
114 Jurnal Administrare: Jurnal Pemikiran Ilmiah dan Pendidikan Administrasi Perkantoran Vol. 7, No. 1, January - June 2020, Pages 109-116

Table 7.

Promotion Hypothesis Test Results on Purchasing Decisions

Coefficients $^{\mathrm{a}}$

\begin{tabular}{|c|c|c|c|c|c|c|}
\hline \multirow{2}{*}{\multicolumn{2}{|c|}{ Model }} & \multicolumn{2}{|c|}{$\begin{array}{c}\text { Unstandardized } \\
\text { Coefficients }\end{array}$} & \multirow{2}{*}{$\begin{array}{c}\text { Standardized } \\
\text { Coefficients } \\
\text { Beta } \\
\end{array}$} & \multirow[b]{2}{*}{$\mathrm{t}$} & \multirow[b]{2}{*}{ Sig. } \\
\hline & & $\mathrm{B}$ & Std. Error & & & \\
\hline & (Constant) & 17.093 & 3.017 & & 5.666 & .000 \\
\hline & Promotion (X2) & .580 & .081 & .605 & 7.132 & .000 \\
\hline
\end{tabular}

a. Dependent Variable: Purchase Decision (Y)

Based on the test results in the above table, the value of $t$ count $>t$ table or $(7.132>1.987)$ is obtained, thus the second hypothesis proposed that there is a significant influence between promotion and purchasing decision is accepted

\section{The Influence of Reputation on Purchasing Decisions}

Correlation coefficient analysis is intended to determine the level of strength of the relationship of the variable of the reputation of the purchase decision variable. The test results are as follows:

Table 8.

Results of Testing the Reputation Correlation Coefficient on Purchasing Decisions Correlations $^{\mathbf{b}}$

\begin{tabular}{llr|r}
\hline & & Reputation (X3) & $\begin{array}{r}\text { Purchase Decision } \\
\text { (Y) }\end{array}$ \\
\hline Reputation (X3) & Pearson Correlation & 1 & $.519^{* *}$ \\
\cline { 2 - 4 } & Sig. (2-tailed) & & .000 \\
\hline Purchase Decision (Y) & Pearson Correlation & $.519^{* *}$ & 1 \\
\cline { 2 - 4 } & Sig. (2-tailed) & .000 & \\
\hline
\end{tabular}

**. Correlation is significant at the 0.01 level (2-tailed).

b. Listwise $\mathrm{N}=78$

Based on the test results obtained by a correlation value of 0.519 means that reputation has a moderate relationship to the purchase decision.

The coefficient of determination analysis is intended to find out the percentage of the effect of the reputation variable on the purchase decision variable. The test results are as follows:

Table 9.

Test Results for the Reputation Determination Coefficient on Purchasing Decisions Model Summary

\begin{tabular}{lr|r|rrr}
\hline Model & & & \multicolumn{2}{|c}{$\begin{array}{c}\text { Std. Error of the } \\
\text { Estimate }\end{array}$} \\
\hline 1 & $\mathrm{R}$ & \multicolumn{2}{c|}{ R Square } & Adjusted R Square & 261 \\
\hline
\end{tabular}

a. Predictors: (Constant), Reputation (X3) 
Based on the test results obtained a determination value of 0.269 means that reputation has a contribution of $26.9 \%$ of the influence on purchasing decisions.

Hypothesis testing with a t-test is used to find out which partial hypotheses are accepted. Third hypothesis: there is a significant influence between reputation on purchasing decisions

Table 10.

Results of Reputation Hypothesis Tests on Purchasing Decisions Coefficients $^{\mathrm{a}}$

\begin{tabular}{|c|c|c|c|c|c|}
\hline \multirow[b]{2}{*}{ Model } & \multicolumn{2}{|c|}{$\begin{array}{c}\text { Unstandardized } \\
\text { Coefficients }\end{array}$} & \multirow{2}{*}{$\begin{array}{c}\text { Standardized } \\
\text { Coefficients } \\
\text { Beta } \\
\end{array}$} & \multirow[b]{2}{*}{$\mathrm{t}$} & \multirow[b]{2}{*}{ Sig. } \\
\hline & $\mathrm{B}$ & Std. Error & & & \\
\hline $\begin{array}{ll}\quad \text { (Constant) } \\
\end{array}$ & 21.598 & 2.987 & & 7.231 & .000 \\
\hline Reputation (X3) & .451 & .079 & .519 & 5.694 & .000 \\
\hline
\end{tabular}

a. Dependent Variable: Purchase Decision (Y)

Based on the test results in the above table, the value of $t$ count $>t$ table or $(5.694>1.987)$ is obtained, thus the third hypothesis proposed that there is a significant influence between reputation on purchasing decisions is accepted.

\section{The Influence of Marketing, Promotion and Reputation Strategies on Purchasing Decisions}

This regression test is intended to determine changes in marketing strategy variables, promo if the purchase decision variable changes. The test results are as follows:

Table 11.

Multiple Linear Regression Testing Results

\begin{tabular}{|c|c|c|c|c|c|c|}
\hline \multicolumn{7}{|c|}{ Coefficients $^{\mathrm{a}}$} \\
\hline & & $\begin{array}{r}\text { Unsta } \\
\text { Coe }\end{array}$ & $\begin{array}{l}\text { lardized } \\
\text { cients }\end{array}$ & $\begin{array}{l}\text { Standardized } \\
\text { Coefficients }\end{array}$ & & \\
\hline \multicolumn{2}{|c|}{ Model } & B & Std. Error & Beta & $\mathrm{t}$ & Sig. \\
\hline & (Constant) & 8.224 & 3.194 & & 2.575 & .012 \\
\hline & Marketing Strategy (X1) & .314 & 077 & .358 & 4.071 & .000 \\
\hline & Promotion (X2) & .261 & .096 & .272 & 2.720 & .008 \\
\hline & Reputation (X3) & .239 & 077 & .276 & 3.103 & .003 \\
\hline
\end{tabular}

a. Dependent Variable: Purchase Decision (Y)

Based on the test results in the above table, the regression equation $\mathrm{Y}=8.224+0.314 \mathrm{X} 1+$ $0.261 \mathrm{X} 2+0.239 \mathrm{X} 3$ is obtained. From the equation it is explained that a constant of 8.224 is interpreted if the marketing, promotion, and reputation strategies do not exist, then there has been a purchase decision value of 8.224 points. The marketing strategy regression coefficient is 0.314 , this number is positive, meaning that every time there is an increase in marketing strategy by 0.314 points, the purchasing decision will also increase by 0.314 points. The promotion regression coefficient of 0.261 , this number is positive, meaning that every time there is an increase in the promotion of 0.261 points, the purchasing decision will also increase by 0.261 points. The reputation regression coefficient is 0.239 , this number is positive, meaning that 
116 Jurnal Administrare: Jurnal Pemikiran Ilmiah dan Pendidikan Administrasi Perkantoran Vol. 7, No. 1, January - June 2020, Pages 109-116

every time there is an increase in reputation by 0.239 points, the purchasing decision will also increase by 0.239 points.

Correlation coefficient analysis is intended to determine the level of strength of the relationship between the variables of marketing strategy, promotion, and reputation of the purchase decision variable. The test results are as follows:

Table 12.

Simultaneous Coefficient Testing Results of Marketing, Promotion and Reputation Strategies Against Purchasing Decisions

Model Summary

\begin{tabular}{|c|c|c|c|c|}
\hline Model & $\mathrm{R}$ & R Square & $\begin{array}{l}\text { Adjusted R } \\
\text { Square }\end{array}$ & $\begin{array}{l}\text { Std. Error of the } \\
\text { Estimate }\end{array}$ \\
\hline$\overline{1}$ & $.717^{\mathrm{a}}$ & .514 & .497 & 2.281 \\
\hline
\end{tabular}

a. Predictors: (Constant), Reputation (X3), Marketing Strategy (X1), Promotion (X2)

Based on the test results obtained by a correlation value of 0.717 means that marketing strategies, promotions, and reputation simultaneously have a strong relationship to purchasing decisions.

The coefficient of determination analysis is intended to find out the percentage of the influence of the marketing strategy, promotion, and reputation variables on the purchase decision variable. Based on the test results obtained a determination value of 0.514 means that simultaneous marketing, promotion, and reputation strategies have an influence contribution of $51.4 \%$ to the purchase decision, while the remaining $48.6 \%$ is influenced by other factors.

Hypothesis testing with the F test is used to find out which simultaneous hypotheses are accepted. The fourth hypothesis There is a significant influence between marketing strategy, promotion, and reputation on purchasing decisions.

Table 13.

Hypothesis Test Results for Marketing, Promotion, and Reputation Strategies Against Purchasing Decisions.

ANOVA $^{\mathrm{a}}$

\begin{tabular}{llr|r|r|r|c}
\hline Model & Sum of Squares & \multicolumn{1}{c|}{ df } & Mean Square & F & \multicolumn{1}{c}{ Sig. } \\
\hline \multirow{2}{1}{1} & Regression & 473.114 & 3 & 157.705 & 30.318 & $.000^{\mathrm{b}}$ \\
\cline { 2 - 7 } & Residual & 447.341 & 86 & 5.202 & & \\
\cline { 2 - 7 } & Total & 920.456 & 89 & & & \\
\hline
\end{tabular}

a. Dependent Variable: Buying decision (Y)

b. Predictors: (Constant), Reputation (X3), Marketing Strategy (X1), Promotion (X2)

Based on the test results in the above table, obtained $F$ count $>F$ table or $(30.318>2.710)$, thus the fourth hypothesis proposed that there is a significant influence between marketing strategy, promotion, and reputation on the purchase decision is accepted. 


\section{Discussion}

\section{The Influence of Marketing Strategies on Purchasing Decisions}

The marketing strategy has a significant effect on purchasing decisions with a correlation of 0.576 or has a moderate relationship with a contribution of $33.2 \%$. Hypothesis testing obtained t count> $t$ table or $(6.607>1.987)$. Thus the first hypothesis proposed that there is a significant influence between marketing strategies on purchasing decisions.

\section{The Influence of Promotion on Purchasing Decisions}

The promotion has a significant effect on purchasing decisions with a correlation of 0.605 or has a strong relationship with a contribution of $36.6 \%$. Hypothesis testing obtained $t$ count $>t$ table or (7.132> 1.987). Thus the second hypothesis is proposed that there is a significant influence between promotion and purchase decision.

\section{The Influence of Reputation on Purchasing Decisions}

Reputation has a significant effect on purchasing decisions with a correlation of 0.519 or has a moderate relationship with a contribution of $26.9 \%$. Hypothesis testing obtained $t$ count $>t$ table or $(5.694>1.987)$. Thus the third hypothesis is proposed that there is a significant effect between promotions on purchasing decisions accepted.

\section{The Influence of Marketing, Promotion and Reputation Strategies on Purchasing Decisions}

Marketing, promotion and reputation strategies have a significant effect on purchasing decisions by obtaining a regression equation $\mathrm{Y}=8.224+0.314 \mathrm{X} 1+0.261 \mathrm{X} 2+0.239 \mathrm{X} 3$, the correlation value of 0.717 or has a strong relationship with the contribution of influence of $51.4 \%$ while the rest of $48,6 \%$ is influenced by other factors. Hypothesis testing obtained by calculating the $F$ value $>F$ table or $(30.318>2.710)$. Thus the fourth hypothesis proposed that there is a significant effect between marketing strategy, promotion and reputation on purchasing decisions is accepted

\section{CONCLUSION}

The marketing strategy has a significant effect on purchasing decisions with an influence contribution of $33.2 \%$. Hypothesis testing obtained $t$ count $>t$ table or $(6.607>1.987)$. The promotion has a significant effect on purchasing decisions with an influence contribution of $36.6 \%$. Hypothesis testing obtained $t$ count $>t$ table or (7.132>1.987). Reputation has a significant effect on purchasing decisions with an influence contribution of 26.9\%. Hypothesis testing obtained $t$ count $>t$ table or (5.694> 1.987). Marketing, promotion, and reputation strategies have a significant effect on purchasing decisions with a contribution of $51.4 \%$ while the remaining $48.6 \%$ is influenced by other factors. Hypothesis testing obtained F count $>\mathrm{F}$ table or $(30.318>2.710)$. 
118 Jurnal Administrare: Jurnal Pemikiran Ilmiah dan Pendidikan Administrasi Perkantoran Vol. 7, No. 1, January - June 2020, Pages 109-116

\section{REFERENCES}

Chenavaz, R. Y., Feichtinger, G., Hartl, R. F., \& Kort, P. M. (2020). Modeling the impact of product quality on dynamic pricing and advertising policies. European Journal of Operational Research, 284(3), 990-1001. https://doi.org/https://doi.org/10.1016/j.ejor.2020.01.035

Deng, Y., Staelin, R., Wang, W., \& Boulding, W. (2018). Consumer sophistication, word-ofmouth and "False" promotions. Journal of Economic Behavior \& Organization, 152, 98 123. https://doi.org/https://doi.org/10.1016/j.jebo.2018.05.011

Farida, U. (2017). Analysis of Empowerment Program that was Implemented in Mamuju Regency East Sulawesi Indonesia. 149(Icest), 19-21.

Ferrara, I., Missios, P., \& Yildiz, H. M. (2019). Product quality, consumption externalities, and the role of National Treatment. European Economic Review, 117, 1-35. https://doi.org/https://doi.org/10.1016/j.euroecorev.2019.04.005

Ferrari, L., Palmieri, A., Pepato, A., Prevedello, A., Dima, R., \& Udup, E. (2017). Production quality controls and geometric characterization of the IFMIF-RFQ modules via the usage of a Coordinate Measuring Machine. Fusion Engineering and Design, 115, 23-32. https://doi.org/https://doi.org/10.1016/j.fusengdes.2016.12.027

Hollensen, S. (2010). Marketing management: A relationship approach. Pearson Education.

Irmal, I., Gustiarani, E., \& Sunarsi, D. (2020). Pengaruh E-Marketing Dan E-CRM Terhadap ELoyalty Pengunjung Situs Website WWW. Cangkirbogor.Com. Jurnal Ekonomi Efektif, 2(2).

Jiménez-Asenjo, N., \& Filipescu, D. A. (2019). Cheers in China! International marketing strategies of Spanish wine exporters. International Business Review, 28(4), 647-659. https://doi.org/https://doi.org/10.1016/j.ibusrev.2019.01.001

Krämer, F., Schmidt, K. M., Spann, M., \& Stich, L. (2017). Delegating pricing power to customers: Pay What You Want or Name Your Own Price? Journal of Economic Behavior \& Organization, 136, 125-140. https://doi.org/https://doi.org/10.1016/j.jebo.2017.01.019

Ma, Z., \& Koutsopoulos, H. N. (2019). Optimal design of promotion based demand management strategies in urban rail systems. Transportation Research Part C: Emerging Technologies, 109, 155-173. https://doi.org/https://doi.org/10.1016/j.trc.2019.10.008

Mani, J. (2018). Pengaruh Persepsi Merek Dan Kualitas Pelayanan Terhadap Kepuasan Pelanggan (Studi Kasus Pada PT. Bisma Narendra Di Jakarta). Jurnal Mandiri. https://doi.org/10.33753/mandiri.v1i2.18

Mead, J. A., Richerson, R., \& Li, W. (2020). Dynamic Right-Slanted Fonts Increase the Effectiveness of Promotional Retail Advertising. Journal of Retailing. https://doi.org/https://doi.org/10.1016/j.jretai.2019.10.002

Niswaty, R., Darwis, M., Alimuddin, W., \& Salam, R. (2016). Pengaruh Penerapan Prinsip 
Good Governance terhadap Efektivitas Kerja Pegawai. Jurnal Ilmiah Administrasi Publik (JIAP), 95-100.

Parola, F., Pallis, A. A., Risitano, M., \& Ferretti, M. (2018). Marketing strategies of Port Authorities: A multi-dimensional theorisation. Transportation Research Part A: Policy and Practice, 111, 199-212. https://doi.org/https://doi.org/10.1016/j.tra.2018.03.012

Peter, J. P., Olson, J. C., \& Grunert, K. G. (1999). Consumer behaviour and marketing strategy. McGraw-hill London.

Roy, S., Modak, N., \& Dan, P. K. (2017). Product Quality as Factors and Measures for New Product Development Success in Indian Manufacturing Industries. Materials Today: Proceedings, 4(2, Part $\quad$ A), 1385-1393. https://doi.org/https://doi.org/10.1016/j.matpr.2017.01.160

Steinhauser, J., Janssen, M., \& Hamm, U. (2019). Consumers' purchase decisions for products with nutrition and health claims: What role do product category and gaze duration on $\begin{array}{llll}\text { claims } & \text { play? } & \text { Appetite, } & 104337 .\end{array}$ https://doi.org/https://doi.org/10.1016/j.appet.2019.104337

Varadarajan, R. (2020). Customer information resources advantage, marketing strategy and business performance: A market resources based view. Industrial Marketing Management. https://doi.org/https://doi.org/10.1016/j.indmarman.2020.03.003

Wen, X., \& Siqin, T. (2020). How do product quality uncertainties affect the sharing economy platforms with risk considerations? A mean-variance analysis. International Journal of $\begin{array}{lll}\text { Production } \quad \text { Economics, } & 224, & 107544 .\end{array}$ https://doi.org/https://doi.org/10.1016/j.ijpe.2019.107544

Yang, B., \& Mattila, A. S. (2020). How rational thinking style affects sales promotion effectiveness. International Journal of Hospitality Management, 84, 102335. https://doi.org/https://doi.org/10.1016/j.ijhm.2019.102335

Zaric, G. S., \& Xie, B. (2009). The Impact of Two Pharmaceutical Risk-Sharing Agreements on Pricing, Promotion, and Net Health Benefits. Value in Health, 12(5), 838-845. https://doi.org/https://doi.org/10.1111/j.1524-4733.2009.00510.x 